Research Article

\title{
The Effectiveness of Geography Learning in the 2013 Curriculum
}

\author{
Dian Rakhmasari *, Inti Nur Tirta, Iqnia Fajril Wahida, M Fajar Septarianto, Shandy Choirul \\ Fatah, Yunia Dwi Karina
}

Department of Geography Education, University of Jember. Jl. Kalimantan 37 Jember, 68121, Indonesia

Article history:

Submission December 2019

Revised August 2020

Accepted August 2020

*Corresponding author:

E-mail:

dianrakhmasari12@gmail.com

\begin{abstract}
This research aims to determine the effectiveness of the use of the 2013 curriculum in geography subjects. Data analysis techniques were used quantitative descriptive analysis to analyze the data in ways that describe or depict the data that has been obtained. This study was used data collection techniques by distributing questionnaires, interviews, and documentation. Data analysis uses descriptive data analysis techniques. The results showed that the use of the 2013 curriculum was still not going well. The effectiveness of learning with the application of the 2013 curriculum in geography is still needed a lot of review and adaptation of characteristics.
\end{abstract}

Keywords: Effectiveness; 2013 curriculum; learning geography

\section{Introduction}

The curriculum is currently developing very rapidly following the times. The development of this curriculum does not always have a good impact related to the learning activities carried out at every school. Curriculum development does not infrequently even make some conditions from administration and learning hours more complicated. Another problem arises when the school is still considered not capable enough to implement the new curriculum which is considered burdensome and makes the facilities and infrastructure available at the school not fully available so that it will disrupt the implementation of the curriculum. In addition to facilities and infrastructure that are still inadequate in the ability of teachers who are required to be able to use computer devices properly, they also become obstacles because not all teachers can use technological developments well. According to Afandi [1], he said that the problems that occurred in implementing the 2013 curriculum were in the teacher and student books, inadequate teacher training, facilities and infrastructure that did not support the realization of effective learning and following the 2013 curriculum, and teachers who experienced difficulties in ICT.

In addition to these problems related to the learning process, some problems are related to administration such as assessment instruments. Just as explained by Darling-Hammond et al. [2] who explained that the problem felt by the teacher lies in the lack of understanding of the teacher's skills in making assessment instruments that currently have a variety of assessments. The number of these assessments poses obstacles because not all teachers are able to memorize their students one by one which causes problems at the assessment stage during the 2013 curriculum.

The same thing was also explained by Retnawati et al. [3] who explained that the implementation of the 2013 curriculum in its implementation had obstacles namely completeness, legibility, timeliness or time allocation, and student administration. The implementation of this curriculum itself is an effort made in implementing and implementing a curriculum that has been designed in the implementation

How to cite:

Rakhmasari D et al. (2020) The effectiveness of geography learning in the 2013 curriculum. Basic and Applied Educational Research Journal 1 (1): 17 - 23. doi: 10.11594/baerj.01.01.03 
of learning [4]. The curriculum itself must be adjusted following the times and eras and adjusted to the needs needed for now. As explained by Mulyasa [5] who explained that curriculum changes and developments need to be done because the curriculum has a dynamic nature to be able to answer the development and challenges of the times. The application of the curriculum is the same as the most important learning objectives can be achieved. As said by Oemar [6] which explains that learning and education processes are provided to achieve the goals of national education especially for quality human resources. Previous research has not focused much on the effectiveness of the geography curriculum in schools. Few researchers concern about curriculum implementation for geography. Therefore, this research aims to determine the effectiveness of the use of the 2013 curriculum in geography subjects.

\section{Research Method}

Design researcher's use of data analysis techniques that quantitative descriptive analysis as to analyze the data in ways that describe or depict the data that has been obtained following facts on the ground. To make conclusions that apply in detail or typical. Using two independent variables namely the effectiveness of geography learning and curriculum policy. The population is part of a generalization consisting of objects or subjects that become certain characteristics determined by researchers to be analyzed and then conclusions are drawn [7]. The population of this research is the Principal, Vice-President of the Curriculum, Geography Teachers, Subject Teachers, Students of MA 1 Jember, and MA 2 Jember. In this study, it is expected that the population can explain in detail about the application of $\mathrm{K}-13$ and KTSP and be able to compare between the two.

The research sample is part or representative of the population taken as a source of information and can represent the entire population [8]. From the total teacher population, that is, all teachers in MA 1 and MA 2 only 30 teachers were taken per school. Then from the total student population, five students have different classes in each school. This study uses questionnaire data collection methods, interviews, and documentation. Questionnaires are useful in knowing the effectiveness of geography learning and curriculum policies in 2013. Before the questionnaire is distributed in data collection, a validity and reliability test for the questionnaire to be used is conducted. Data management can be known by researchers about the meaning of the data that has been collected [9]. That way the research results can be obtained accurately. In facilitating data analysis using computer assistance with programs in the form of tables or graphs.

\section{Results and Discussion Results}

Table 1. Results of questionnaire MA Negeri 1 Jember (Senior High School 1)

\begin{tabular}{clcccc}
\hline \multicolumn{1}{c}{ Question } & Yes & No & KTSP Curriculm & K-13 Curriculum \\
\hline 1 & $\begin{array}{l}\text { Easier document preparation } \\
\text { for KTSP or K-13. }\end{array}$ & - & - & 14 & 4 \\
2 & $\begin{array}{l}\text { RPP that is superior to KTSP or } \\
\text { K-13 }\end{array}$ & - & - & 10 & 3 \\
3 & $\begin{array}{l}\text { Easier assessment between SK } \\
\text { (KTSP) and KI (K-13) } \\
\text { KD which is superior to K-13 or } \\
\text { KTSP }\end{array}$
\end{tabular}

Continued.... 
D Rakhmasari et al., 2020 / The effectiveness of geography learning in the 2013 curriculum

\begin{tabular}{|c|c|c|c|c|c|}
\hline NO. & Question & Yes & No & KTSP Curriculm & K-13 Curriculum \\
\hline 5 & $\begin{array}{l}\text { Which of the indicators of } \\
\text { achievement for K- } 13 \text { and KTSP } \\
\text { is more effective in its applica- } \\
\text { tion. }\end{array}$ & - & - & 11 & 7 \\
\hline 6 & $\begin{array}{l}\text { More efficient where TP K-13 } \\
\text { and KTSP. }\end{array}$ & - & - & 13 & 5 \\
\hline 7 & $\begin{array}{l}\text { Are there differences in learning } \\
\text { outcomes from MP KTSP and K- } \\
13 .\end{array}$ & 16 & 2 & - & - \\
\hline 8 & $\begin{array}{l}\text { Using the learning model of sci- } \\
\text { entific / contextual methods or } \\
\text { still using the lecture method. }\end{array}$ & - & - & - & - \\
\hline 9 & $\begin{array}{l}\text { Are there differences in learning } \\
\text { media between K-13 and KTSP. }\end{array}$ & 14 & 4 & - & - \\
\hline 10 & $\begin{array}{l}\text { More effective KTSP learning re- } \\
\text { sources in the form of books or } \\
\text { K-13 learning that have wider } \\
\text { sources. }\end{array}$ & - & - & 13 & 5 \\
\hline 11 & $\begin{array}{l}\text { Are there differences in KTSP } \\
\text { and K-13 learning steps. }\end{array}$ & 15 & 3 & - & - \\
\hline 12 & $\begin{array}{l}\text { Are each KTSP subjects with K- } \\
13 \text { supporting the results of } \\
\text { each student's learning compe- } \\
\text { tency. }\end{array}$ & 14 & 4 & - & - \\
\hline 13 & $\begin{array}{l}\text { Did you prepare for K-13 learn- } \\
\text { ing? }\end{array}$ & 18 & - & - & - \\
\hline 14 & $\begin{array}{l}\text { Do you take action to overcome } \\
\text { the obstacles you are experienc- } \\
\text { ing and how the efforts of the fa- } \\
\text { ther/mother to handle them. }\end{array}$ & 18 & - & & - \\
\hline
\end{tabular}

Based on the questionnaire results table 1 , in learning at MAN 1 Jember using the 2013 curriculum, it cannot yet be said to be going well. Besides being supported by existing facilities, several factors are the cause. From interviews conducted on students and students at MAN 1 Jember, they sometimes still find it difficult to understand the material being taught. Before starting the learning activities of teachers in MAN 1 Jember prepares everything science-related processes and learning activities that will begin as learning materials, media and methods to be used concerning all efisien learning will take place. At MAN 1 Jember, students have difficulty in accepting the material provided. In the 2013 curriculum, the addition of hours at school is beneficial, because students can be active and study longer in school. The implementation of the 2013 curriculum had several obstacles, such as the way of teaching, the material, the media, student activity, and infrastructure suggestions. However, in MAN 1 Jember, the school is working on facilities and infrastructure currently under construction to support and run the 2013 curriculum. Even the latest revision curriculum has also been implemented and besides that every new school year a review of the curriculum is conducted before a new one is formed. a team that reviews KTSP and is authorized by the Ministry of Religion. Facilities are also availa- 
ble, such as computers, LCD projectors, libraries, laboratories and so on. In applying the 2013 curriculum, not all of them succeeded in making students and students understand more about the material. Depending on how the mental condition and understanding of students and students. In implementing the curriculum, the teacher is also involved in this matter as a mentor and supervisor so that students also see how they are developing in learning one semester before and after. Besides, the assessment conducted by the teacher can be in the form of observation sheets and observations separately to assess and know the attitudes and behavior during and outside the classroom.

Table 2. Results of questionnaire MAN 2 Jember (Senior High School 2)

\begin{tabular}{|c|c|c|c|c|c|}
\hline NO. & QUESTION & YES & No & KTSP Curriculum & K-13 Curriculum \\
\hline 1. & $\begin{array}{l}\text { Easier document preparation for } \\
\text { KTSP or K-13. }\end{array}$ & - & - & 7 & 13 \\
\hline 2 & $\begin{array}{l}\text { RPP that is superior to KTSP or K- } \\
13\end{array}$ & - & - & 2 & 18 \\
\hline 3 & $\begin{array}{l}\text { Easier assessment between SK } \\
\text { (KTSP) and KI (K-13) }\end{array}$ & - & - & 10 & 10 \\
\hline 4 & $\begin{array}{l}\text { KD which is superior to K-13 or } \\
\text { KTSP }\end{array}$ & - & - & 2 & 18 \\
\hline 5 & $\begin{array}{l}\text { Which of the indicators of } \\
\text { achievement for K-13 and KTSP } \\
\text { is more effective in its applica- } \\
\text { tion. }\end{array}$ & - & - & 7 & 13 \\
\hline 6 & $\begin{array}{l}\text { More efficient where TP K-13 and } \\
\text { KTSP. }\end{array}$ & - & - & 15 & 5 \\
\hline 7 & $\begin{array}{l}\text { Are there differences in learning } \\
\text { outcomes from MP KTSP and K- } \\
13 .\end{array}$ & 19 & 1 & & \\
\hline 8 & $\begin{array}{l}\text { Using the learning model of sci- } \\
\text { entific / contextual methods or } \\
\text { still using the lecture method. }\end{array}$ & - & - & - & - \\
\hline 9 & $\begin{array}{l}\text { Are there differences in learning } \\
\text { media between K-13 and KTSP. }\end{array}$ & 19 & 1 & - & - \\
\hline 10 & $\begin{array}{l}\text { More effective KTSP learning re- } \\
\text { sources in the form of books or K- } \\
13 \text { learning that have wider } \\
\text { sources. }\end{array}$ & - & - & 3 & 17 \\
\hline 11 & $\begin{array}{l}\text { Are there differences in KTSP and } \\
\text { K-13 learning steps. }\end{array}$ & 2 & 18 & - & - \\
\hline 12 & $\begin{array}{l}\text { Are each KTSP subjects with K- } \\
13 \text { supporting the results of each } \\
\text { student's learning competency. }\end{array}$ & 1 & 19 & - & - \\
\hline 13 & $\begin{array}{l}\text { Did you prepare for K-13 learn- } \\
\text { ing? }\end{array}$ & 20 & - & - & - \\
\hline 14 & $\begin{array}{l}\text { Do you take action to overcome } \\
\text { the obstacles you are experienc- } \\
\text { ing and how the efforts of the fa- } \\
\text { ther/mother to handle them? }\end{array}$ & 20 & - & - & - \\
\hline
\end{tabular}

Based on table 2, Learning at MAN 2 Jem- be quite good. This was supported by the origiber using the 2013 curriculum is said to nal data from the questionnaire distributed by 
20 teachers and interviews with 5 students. In the implementation of learning activities that will be carried out by teachers at MAN 2 Jember, they will design learning structures so that students when the teacher submits the material while in class are easier to understand. When interviewing the 5 students, many of MAN 2 Jember students were still having difficulty understanding the material presented by the teacher. This is certainly an obstacle for teachers to achieve the main objectives of learning, for that when teaching teachers are required to prepare everything related to media, methods, materials that will be used in the classroom. With this, students and students find it easier to understand the material delivered by the teacher. With the change in the curriculum, it makes students spend more time in school to learn and develop their skills through hours of specialization classes and skills. However, behind it, the teacher experiences many obstacles, such as the lack of facilities, students and students who do not fit into the curriculum, the difficulty of the teacher in supervising or monitoring the development of their students because indeed with so many students the teacher has difficulty with it. In MAN 2 Jember, facilities, and infrastructure can be said to be inadequate but the school itself is optimizing its development and trying to complement the facilities there. it's Elain teachers judging from academic, teachers also assess the behavior and character of male and female students using the observation sheet. So, assessment can come from outside the classroom. Also, the teacher uses the observation width to assess student skills and assess student activity in class.

\section{Discussion}

The successful implementation of the 2013 curriculum is not only on the accuracy and comprehensiveness of the formulation of SKL (Graduates Competency Standards) and the basic framework, and curriculum structure, but from the principal's leadership at the education unit level and teacher leadership at the class level. The principal's leadership has an important role in moving the teaching force and also making decisions for improving school conditions in a better direction and in facilitating teachers in carrying out teaching and learning in the classroom. Whereas teacher leadership at the classroom level also becomes an inseparable part of the success of the 2013 curriculum. Teachers are the foremost actors in implementing the 2013 curriculum dealing with students. The important role of the teacher, among others, is to describe the topic of the material into interesting and easy-to-understand information for students, identify the level of difficulty of students, and the ability to help them get out of trouble, and evaluate student learning progress. Based on the evaluation results teachers can determine strategies to determine the right method in providing information in the form of knowledge to students. Thus, the creativity of the teacher is very important for the optimal distribution of the material learned and easily understood by students. The learning process related to the implementation of the 2013 curriculum in each subject area needs to be reviewed and adapted to the characteristics of the subjects according to the provisions in the curriculum rules. Each subject has its characteristics and difficulties, so there will be differences in the learning process and learning management [10]. Mathematics subjects in the learning process will be different from the eyes of Indonesian language subjects. Similarly, the subject of geography also has characteristics that are different from other subjects. So that the rules in the curriculum cannot be applied in a monotonous way but in various ways but with points still meeting each of the existing indicators.

Geography subjects have characteristics in the form of concrete and partially abstract study objects, this is in line with Maryani [11] that in geography there are spatial aspects which are physical elements in the form of the earth's surface and human elements that run a state and process of space. Students will be able to find out about a phenomenon, interaction between spaces, interruption, interdependence, and various phenomena if it can be forgotten in the form of tables, pictures, maps, statistics, and through audio and video. Students will know the role of interaction between spaces when problems occur in meeting needs. 
Geography study with unique characteristics will have its uniqueness in the process of learning geography in schools. With various facilities such as pictures or tables which are one of the indicators in the 2013 curriculum, students are expected to be able to understand various phenomena and processes of surface change. Various phenomena and processes in a space are not enough just to know by mentioning names and terms, but educators must be able to have sources of information or be able to show illustrations of phenomena in concrete ways.

Geography phenomena and processes which are typical studies in geography subjects need to be understood by students with things that are easily digested such as the existence of learning media. Learning media that can be used when learning geography can be in the form of graphs, tables, maps, pictures, animations, and video lessons [12]. So that geography material can be easily digested and understood by students after being processed to be more concrete. The 2013 curriculum emphasizes a scientific approach, where this approach invites students to carry out the research process. In this model, students are trained to research scientific problem-solving. It is hoped that with the existence of this synthetic model students can develop scientific attitudes and build learning skills. The research steps are the foundation for developing the learning process.

Approach scientific scientifically based by Subiyanto [13] Run to ng coup two aspects of skill, which aspects of basic skills (consisting of observation, classification, communication, measurement, prediction, and conclusion) and the skill aspect integrated (comprising the identification of variables, create tables data, create charts, construct hypotheses and conduct experiments. Skills learning process consisted of nine steps of observation, interpretation, classification, prediction, communication, hypothesize, design experiments, apply concepts, and ask questions [14]. Curriculum 2013 which emphasizes the scientific approach to the implementation process, is very easy to do in geography learning. The process of implementation in learning activities will be easy if secondary data is available that can be obtained from authorized agencies such as the Disaster Management Agency, Statistics Indonesia, population data, thematic maps, etc. that are needed in the research process (scientific). Then if the field observation area is close enough to the school it will further support the scientific learning process, so students can carry out observation activities to obtain data easily. But the scientific learning process will be difficult to apply in the learning process if the educator does not have concrete data, the unavailability of learning tools and media, and field observation locations far from the school. In its application, the 2013 curriculum has several advantages in the effectiveness of learning in geography subjects in MAN 1 and MAN 2 Jember this is due to the preparation of documents in the teaching and learning process more easily and concisely. Curriculum 2013 also has source broader curriculum which in 2013 had the characteristics of learning using the approach scientifically. Scientific learning is learning that makes science a method or approach in the teaching and learning process so that learning will make students more creative and more active.

\section{Conclusion}

The curriculum is currently developing very rapidly following the times. The development of this curriculum does not always have a good impact related to geography learning activities carried out at every school. In the learning process related to the implementation of the 2013 curriculum in geography, it is necessary to review and adapt the characteristics of the subjects because each subject has its characteristics and difficulties. The 2013 curriculum has several advantages in the effectiveness of learning in geography subjects. This is because the preparation of documents in the learning process is easier and more concise and is supported by extensive teaching resources.

\section{Acknowledgment}

The authors say thanks to Department of Geography Education, University of Jember for supporting and facilitating this research. 


\section{References}

1. curriculum in preparing indonesian human resources for the "Asean Economic Community" in 2015. In Proceedings of the National Education Seminar, The Theme Curriculum Implementation.

2. Darling-Hammond L, Flook L, Cook-Harvey C, Barron B, Osher D (2020). Implications for educational practice of the science of learning and development. Applied Developmental Science 24(2): 97-140 https://doi.org/10.1080/10888691.2018.1537791

3. Retnawati H, Hadi S, Nugraha AC (2016) Vocational high school teachers' difficulties in implementating the assessment in curriculum 2013 in Yogyakarta Province of Indonesia. International Journal of Instruction 9(1): 33-48. doi 10.12973/iji.2016.914a

4. Kurniasih I, Berlin S (2014) Implementation of the 2013 concept \& implementation curriculum. Surabaya, Pena words.

5. Mulyasa (2013) Development and implementation of the 2013 curriculum. Bandung, PT Remaja Rosdakarya.

6. Oemar H (2011) Curriculum and Learning. Jakarta, PT Bumi Aksara, p. 24

7. Majid U (2018) Research fundamentals: Study design, population, and sample size. URNCST Journal 2(1): 1 7.doi.org/10.26685/urncst.16
8. Al Kindy AMZ, Mad Shah I, Juson A (2016) Consideration and methodological approaches in studying transformational leadership impac on work performance behaviors. International Journal of Advanced Research 4(1): 889-907.

9. George G, Haas MR, Pentland A (2014) Big data and management. The Academy of Management Journal 57(2):321-326. doi: $\underline{10.5465 / \mathrm{amj} .2014 .4002}$

10. Ioannidi V, Samara E (2019) Chidren with learning difficulties and conditions of school inclusion-a brief report and a constant challenge of inclusive education. European Journal of Education Studies 6(3): 1-7.

11. Maryani E (2009) Compilation of Geography Education in Social Sciences Context. Bandung, Department of Geography Education FPIPS UPI

12. Musarofah F (2014) Readiness and constraints of High School Geography subject teachers in the context of implementing the 2013 curriculum in Magelang City. Yogyakarta State University.

13. Subiyanto (2009) Natural sciences education. Jakarta, Educational Workforce Education Institution Development Project (P2LPTK).

14. Safaah ES, Muslim M, Liliawati W (2017) Teaching science process skills by using the 5-stage learning cycle in Junior High School. Journal of Physics Conference Series 895(1):012106. doi: $\underline{10.1088 / 1742-6596 / 895 / 1 / 012106}$ 